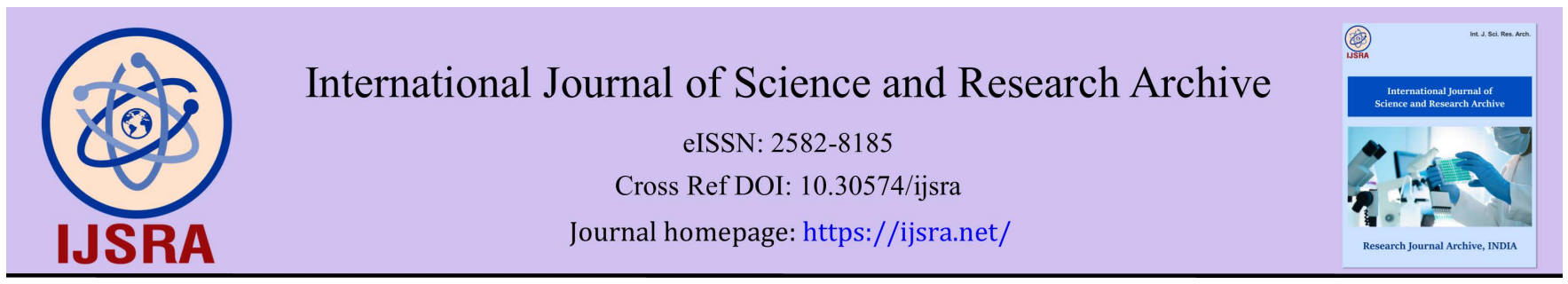

(RESEARCH ARTICLE)

\title{
Organizational culture as a variable of leadership moderation and employee job satisfaction towards the organizational performance of PT. WKS Jambi
}

\author{
Noviardi Ferzi * \\ Department of Management, Sekolah Tinggi Ilmu Ekonomi (STIE) Jambi, Indonesia
}

International Journal of Science and Research Archive, 2021, 02(02), 087-098

Publication history: Received on 18 March 2021; revised on 25 April 2021; accepted on 27 April 2021

Article DOI: https://doi.org/10.30574/ijsra.2021.2.2.0064

\begin{abstract}
How is the influence of leadership style and work environment on employee job satisfaction with organizational culture as a moderating variable at the PT WKS Jambi? This research uses quantitative methods. The data analysis used the structural-partial least square equation model. Eighty-four employees from each company plantation district were used as samples. The results showed that: 1). leadership style affects the work environment; 2). leadership style has a significant effect on organizational culture; 3). the work environment does not affect organizational culture; 4). organizational culture has a strong relationship with job satisfaction; 5). Leadership style does not affect job satisfaction; 6). the work environment does not affect job satisfaction; 7). through organizational culture, leadership style has a significant effect on job satisfaction; and 8. through organizational culture, the work environment does not significantly affect job satisfaction.
\end{abstract}

Keywords: Leadership Style; Work Environment; Organizational Culture; Job Satisfaction

\section{Introduction}

As a large global company in the forestry sector, PT. Wira Karya Sakti (WKS) has the vision to become a world-class company that practices sustainable forest management by developing harmonious social relationships, economically feasible and environmentally friendly. PT. WKS is supported by a concession area of 290,378 hectares and is supported by 16,432 permanent and contract employees spread over 8 (eight) land and administrative districts [1].

Productivity PT. WKS has a good performance. It is proven by the company's ability to produce 4 million tons of raw material for paper powder each year. On the other hand, the turnover rate of employees in and out of work is categorized as high. It can be seen from the average number of employees who quit their job at an average of $16 \%$ per year. According to Rozman \& Strukelj [2], the company's LTO level shows a low level of employee satisfaction. Also, in another study, it is stated that the level of employee satisfaction encourages organizational performance [3], [4], [5]. This condition is interesting to examine the extent to which job satisfaction factors affect organizational performance at PT. WKS.

Job satisfaction is considered one of the factors that affect organizational performance. So far, job satisfaction is assessed as employees' feelings about the performance results that have been done. Job satisfaction is a happy emotional state or positive emotion from appraising one's job or work experience [6]. However, research by Davidescu, [7] states that many factors affect the level of satisfaction at work so that the level of satisfaction obtained by each employee will also be different.

\footnotetext{
${ }^{*}$ Corresponding author: Noviardi Ferzi

Department of Management, Sekolah Tinggi Ilmu Ekonomi (STIE) Jambi, Indonesia

Copyright $(2021$ Author(s) retain the copyright of this article. This article is published under the terms of the Creative Commons Attribution Liscense 4.0.
} 
The success of the organization in achieving its goals is also determined by leadership. Leadership is a process based on interactions between leaders and subordinates. The leader must be able to coordinate the existing resources in the organization. Besides, the leader must be able to create a conducive work environment. A bad leader, for example: has an authoritarian nature, does not want to hear suggestions from subordinates, always creates conflict. Whereas examples of good leaders include: willingness to listen to suggestions from subordinates, have high integrity, have good exemplary traits.

Another factor related to job satisfaction is the work environment. According to Ramli, [8], the work environment is everything around the worker and can affect him in carrying out his duties. Hidayati et al. [9] stated that the physical work environment affects morale. A physical environment is a place where an employee completes work in his office. A bad work environment causes inconvenience for employees in carrying out work. Conversely, a good work environment will give employees a sense of calm and comfort in carrying out work.

Culture has been inherent in someone from the environment. Culture will not be easy to get rid of in a relatively short time. According to Abdullah [10], culture is defined as a mixture of values, beliefs, communication, and behavior that serve as guidelines for humans influenced by behavior, norms, and beliefs that become strong communication among workers. Culture will affect the employees concerned and the organization.

Bad organizational culture can be seen from the frequent late arrival rate at the office, too long rest periods, and the habit of receiving tips. Conversely, a good organizational culture, for example: attendance and return from work on time, high involvement in the organization, willingness to come to the office even though they do not receive overtime pay. Paramita [11] concluded that organizational culture has a positive and significant relationship to job satisfaction.

Researchers are very interested in examining the relationship between organizational culture, work environment, and leadership style concerning employee job satisfaction at PT. WKS. The formulations of the problems in this study are: 1) Does leadership style affect the work environment ?; 2) Does the leadership style affect the organizational culture ?; 3) Does the work environment affect organizational culture ?; 4) Does organizational culture affect job satisfaction ?; 5) Does leadership style affect job satisfaction ?; 6) Does the work environment affect job satisfaction ?; 7) Does organizational culture function as a mediating variable in the relationship between leadership style and job satisfaction ?; and 8) Does organizational culture function as a mediating variable in the relationship between work environment and job satisfaction?

\section{Theoretical study}

\subsection{Leadership}

In an organization, a leader is needed who can coordinate all the components in it. According to Strait [12], leadership is a person's process of influencing a group of people to achieve goals. In the present times, leaders do not rely on their power to persuade others to do their will. Still, they interact with subordinates to increase subordinates while maintaining a distance from subordinates.

For the organization to achieve its goals, it must have a vision and mission. To achieve this, it must use appropriate planning, organizing, controlling, monitoring and strategy. Therefore we need a leader who can coordinate all those involved in an organization. According to Cakir \& Adiguzel [13], leadership is a behavior that directs a group of people to fulfill and achieve the goals and mission of the organization. While Setiawan [14], leadership is a process based on the interaction between leaders and subordinates to become effective from change and development and influence the behavior and motivation of followers. Furthermore, according to Sulla \& Perini [15], through case studies and questions state that leadership practice is a "challenging process" to inspire vision, namely: enable others to act (invite action to others), the way model, encourage the heart (impulse).

\subsection{Work environment}

The work environment is a source of job satisfaction; complaints about the work environment are symbols or manifestations of deep frustration because it needs management's attention. Therefore, the aspect of the work environment is closely related to the performance of employees. According to Massoudi \& Hamdi [16], the work environment is everything around the worker and can affect him in carrying out his duties. Meanwhile, the environment are the factors outside and within reach of an organization that can create an opportunity or threat [17]. 
Putri et al. [18] stated that the work environment affects morals, namely the physical environment. A physical environment is a place where an employee completes work in his office. Workplace conditions that are closely related to the work environment, such as: lighting, sound, air conditions, and so on. The work environment is divided into: (a) the physical environment: ventilation/lighting, layout, and equipment, (b) the psycho-social: employees will be able to interact with a positive effect easily [19]. Furthermore, Diamantidis \& Chatzoglou [20], argued that the factors that can influence the formation of a work environment are related to the ability of employees, including: (1) lighting/light, (2) temperature, (3) humidity, (4) ) air circulation, (5) noise, (6) relationship among colleagues, (7) smells, (8) facilities, (9) association with superiors, (10) facilities, (11) security.

\subsection{Organizational culture}

Organizations that have employees with different cultural backgrounds will certainly carry various norms. Every organization has its own culture, which is different from other organizations. According to Pathiranage [21], organizational culture is conceptualized and shared on the beliefs and values of the organization that help shape employee behavior. Meanwhile, according to Erdurmazlı [22], organizational culture is a shared perception held by members within the organization, which differentiates it from other organizations.

Indicators in organizational culture, according to Kuswati [23], are: (1) norm, namely the standard of behavior in the group that is acceptable to the group; (2) dominant values, the support and expectations of organizational members to share with the dominant values; (3) psychology, namely organizational trust as a policy guideline as employees and customers must be safeguarded; (4) climate, namely the overall atmosphere that is conveyed in the organization with a physical layout, and the way employees interact with customers.

Nastaran et al. [24] argued that there are 6 characteristics in identifying organizational culture: (1) Observed behavior regulation, namely: when organizational partisans are related to each other, it interacts between members of the organization and interactions between members with people associated with each other. The organization then will use the same language, terminology, and spirituality with respect and a way of acting; (2) Norm, namely existing standards of behavior, including guidelines on what not to do; (3) Dominant values, namely: there are a number of main values that the organization recommends and expects to members of the organization to contribute, for example: low attendance and high efficiency; (4) Philosophy, namely there are a number of policies that state organizational beliefs about how employees and society as customers are treated; (5) Rules, namely there are a number of definite guidelines that are related, namely a number of definite guidelines relating to progress or ways of relating to the organization. New employees must learn the existing ties or values to be fully accepted as new members of the organization; (6) Organizational climate, namely: the individual brings a feeling, the way members treat themselves to face the community parties from outside.

\subsection{Job satisfaction}

Employees who work are not only looking for money but also looking for satisfaction. That means that satisfaction is a need that every employee craves. According to Dziuba et al. [25], job satisfaction is important for employees and the organization. The urgency is related to the empirical facts that satisfaction shows work experience and high disappointment levels that help show organizational problems that need attention. Also, job disappointment is closely related to absences, employee turnover, and physical and mental health problems. Moreover, when employees are dissatisfied with their work, job involvement is reduced, commitment to the organization is low, the atmosphere is very negative, and a series of negative consequences will arise. Dissatisfied employees may engage in psychological deterioration, physical deterioration (unreasonable absences, early return, prolonged rest, or tardiness), or acts of excessive aggression and retaliation for impressions.

On the other hand, Subramanian [26] stated that satisfied employees could make customer service actions beyond their call of duty, make good reports, and be active in all work areas. It suggests that job satisfaction is very important and vital for the lives of employees and organizations, so that its existence needs to be maintained and improved from time to time. According to Jiang \& Lavaysse, [27] job satisfaction includes reactions or cognitive, affective, and evaluative and states that job satisfaction is "a happy emotional state or positive emotion that comes from appraising one's job or work experience". Job satisfaction is the result of employees' perceptions of how well their job provides things that are considered important.

The factors that influence job satisfaction according to Sutoro, [28] are: 1) Real work: work environment, work situation, position, communication network; 2) Summary of work: those related to supervision, co-workers, democratic functions, behavior, and morals; 3) Psycho-social: those related to social status, promotion, behavior; 4) economic aspects: namely salaries and wages; and 5) community growth: namely contribution to national economic growth and quality of life. 
Meanwhile, according to Shukri et al. [29] factors that influence job satisfaction are: 1) work environment; 2) salary; 3) promotion; and 4) supervision.

\subsection{Research Hypothesis}

It is suspected that there is an influence of

- Leadership style on the work environment.

- Leadership style on organizational culture.

- Work environment on organizational culture.

- Organizational culture on job satisfaction.

- Leadership style on job satisfaction.

- Work environment on job satisfaction.

- Organizational culture functioning as a mediating variable in the relationship between leadership style and job satisfaction.

- Organizational culture functioning as a mediating variable in the relationship between work environment and job satisfaction.

\section{Research methods}

This research was conducted at PT. WKS Jakarta. This research uses a quantitative approach, survey methods and correlational techniques. The subjects of this research are permanent employees who work at PT. WKS except for the Directors and District Heads as many as 87 people. The research sample consisted of 84 people with census techniques.

Primary data were collected by distributing questionnaires designed in the form of a Likert scale and a rating scale. Data analysis used in this research includes: descriptive statistical analysis, classical assumption test (analysis requirements), and parametric statistical analysis (interference). The data analysis method used in this research is Partial Least Square (PLS) - Structural Aquation Modeling (SEM). This study is more predictive of and explains latent variables rather than testing a theory. The sample size of this study is relatively small and anticipates if the data is not normally distributed, Malhotra, [30].

In the structural model, there are 4 (four) inner variables in this study, consisting of: Leadership Style (X1), Work Environment (X2) as the independent variable, Organizational Culture (Y), and Job Satisfaction (Z). In the outer model measurement model, the formation of latent variables in this study reflects that the four latent variables affect the indicator. Of all the variables, there are 15 (fifteen) dimensions and 39 (thirty-nine) indicators, which include: the leadership style variable has 4 (four) dimensions and 15 (fifteen) indicators, the work environment has 2 (two) dimensions, and 7 (seven) indicators, organizational culture has 2 (two) indicators and 12 (twelve) indicators, job satisfaction has 5 (five) dimensions and 5 (five) indicators. PLS-SEM evaluation for the evaluation of the outer model uses a reflective model, which consists of: (1) reliability indicator, with a value of $0.5-0.7$; (2) discriminant validity, with the terms AVE, $>0.6$; (3) internal consistency, with the condition, that composite reliability $\leq 0.6$ (4) Convergent Validity AVE $>0.5[31]$.

\section{Research results and discussion}

\subsubsection{Measurement Model}

The validity of the measurement model and the reliability are reviewed with $>0.50$. And for reliability criteria with AVE value $\geq 0.50$ and $C R \geq 0.70$. Table 1 shows the results of the composite reliability test. 
Table 1 Composite Reliability (CR) Test Results

\begin{tabular}{|l|l|l|l|l|l|l|}
\hline No & Variable & Dimensions & Validity & AVE & CR & Reliability \\
\hline \multirow{3}{*}{1} & \multirow{2}{*}{ Leadership Style } & 1 & Valid & 0,438 & 0,756 & Reliable \\
\cline { 3 - 7 } & & 2 & Valid & 0,481 & 0,787 & \\
\cline { 3 - 7 } & & 3 & Valid & 0,660 & 0,795 & \\
\cline { 3 - 7 } & \multirow{2}{*}{2} & 4 & Valid & 0,717 & 0,835 & \\
\hline \multirow{2}{*}{3} & \multirow{2}{*}{\begin{tabular}{l} 
Work environment \\
\cline { 3 - 7 }
\end{tabular}} & 1 & Valid & 0,427 & 0,748 & Reliable \\
\cline { 3 - 7 } & culture & 2 & Valid & 0,708 & 0,829 & \\
\cline { 3 - 7 } & 2 & Valid & 0,343 & 0,717 & Reliable \\
\cline { 3 - 7 } & 2 & Valid & 0,395 & 0,796 & \\
\hline
\end{tabular}

Based on the results of the above calculations, the leadership style variable consisting of dimension 1 with AVE value (0.438), dimension 2 with AVE value (0.481), dimension 3 with AVE value (0.660), and dimension 4 with AVE value (0.717) are stated reliable. Work environment variables consisting of dimension 1 with AVE value (0.427), dimension 2 with AVE value (0.708), are declared reliable. Furthermore, the organizational culture variable consisting of dimension 1 with an AVE value (0.343), dimension 2 with an AVE value (0.395), is declared reliable. And the job satisfaction variable consisting of: dimension 1, dimension 2, dimension 3 does not have an AVE value, meaning that all indicators in each dimension can directly affect the latent variable (job satisfaction), without having to go through the dimensions first.

The results of the analysis confirmation test (CFA) for each variable can be seen in the table below;

Table 2 Validity Test Results (CFA)

\begin{tabular}{|l|l|l|l|l|l|}
\hline No & Variable & Validity & $\begin{array}{l}\text { AVE } \\
\text { (Indicator) }\end{array}$ & CR & Reliability \\
\hline 1 & Leadership Style & Valid & 0,326 & 0,858 & Reliable \\
\hline 2 & Work environment & Valid & 0,289 & 0,725 & Reliable \\
\hline 3 & $\begin{array}{l}\text { Organizational } \\
\text { culture }\end{array}$ & Valid & 0,283 & 0,820 & Reliable \\
\hline 4 & Job satisfaction & Valid & 0,285 & 0,676 & Reliable \\
\hline
\end{tabular}

Based on table 2 above, it can be seen that all standardized loading factor values are CR values of all variables with values $\geq 0.6$. However, the overall score is statistically significant. Therefore it can be concluded that all indicators of each variable are valid and reliable.

\subsection{Structural Model Analysis}

Structural Model Analysis deals with coefficients or parameters that show the effect of the relationship between latent variables on other latent variables. Based on the results of the questionnaire calculations for respondents that have been collected and processed using SEM-PLS, a structural model is obtained as follows. 


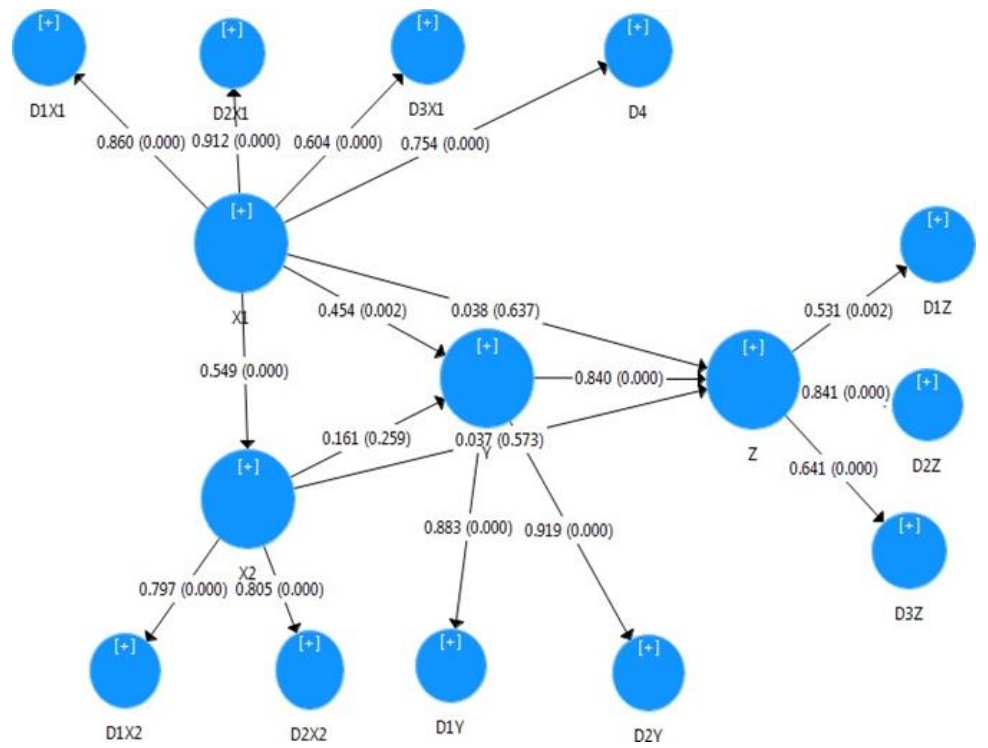

Figure 1 Path Coefisien

The structural model is used to test the research hypothesis. The recapitulation of the results of hypothesis testing based on the P-value is as follows.

Table 3 Hypothesis Test

\begin{tabular}{|c|c|c|c|}
\hline Hypothesis & Path & $\begin{array}{l}\mathrm{P} \\
\text { value }\end{array}$ & Conclusion \\
\hline $\mathrm{H} 1$ & Leadership Style $\rightarrow$ Work environment & 0,000 & Data Supporting Hypotheses \\
\hline $\mathrm{H} 2$ & Leadership Style $\rightarrow$ Organizational culture & 0,002 & Data Supporting Hypotheses \\
\hline H3 & Work environment $\rightarrow$ Organizational culture & 0,259 & $\begin{array}{l}\text { Data Does Not Support } \\
\text { Hypothesis }\end{array}$ \\
\hline $\mathrm{H} 4$ & Organizational culture $\rightarrow$ Job satisfaction & 0,000 & Data Supporting Hypotheses \\
\hline H5 & Leadership Style $\rightarrow$ Job satisfaction & 0,637 & $\begin{array}{l}\text { Data Does Not Support } \\
\text { Hypothesis }\end{array}$ \\
\hline H6 & Work environment $\rightarrow$ Job satisfaction & 0,573 & $\begin{array}{l}\text { Data Does Not Support } \\
\text { Hypothesis }\end{array}$ \\
\hline $\mathrm{H} 7$ & $\begin{array}{l}\text { Leadership Style } \rightarrow \text { Organizational culture } \rightarrow \text { Job } \\
\text { satisfaction }\end{array}$ & 0,002 & Data Supporting Hypotheses \\
\hline H8 & $\begin{array}{l}\text { Work environment } \rightarrow \text { Organizational culture } \rightarrow \text { Job } \\
\text { satisfaction }\end{array}$ & 0,259 & $\begin{array}{l}\text { Data Does Not Support } \\
\text { Hypothesis }\end{array}$ \\
\hline
\end{tabular}

\subsection{Interpretation of Research Hypotheses}

The measurement model analysis in this study shows that all variables have met the criteria for validity and reliability. The following describes the interpretation of the research hypothesis.

\subsubsection{Leadership Style Against Work Environment}

The H1 test results show that the leadership style has a positive relationship with the work environment. If the leadership style is good, then PT. WKS will be able to form a good work environment. Conversely, if the leadership style is not good, then PT. WKS will form an unfavorable work environment. 
In periodic periods in the span of 2 to 5 years, there are always changes of leaders at the district level. Leaders have different cultural and educational backgrounds. Some leaders have senior employee backgrounds and are transfers from similar companies. According to Khajeh, [32] in a journal entitled Impact of Leadership Styles on Followers' Job Satisfaction: A Four Frame Model Approach, leadership is an action to lead a group of people to achieve the goals of the organization. Leadership will help employees to answer organizational goals in general when their leadership influences employees.

One form of leadership style is how a leader influences his subordinates to work diligently and motivates his subordinates to work. Nadolna, [33] states that leadership is a behavior that directs a group of people to fulfill and achieve the goals and mission of the organization. It is supported by research conducted by Rahbi et al. [34], who proved that transformational leadership has a negative relationship to inspirational motivation $(\beta=1 / 4-0.22 ; p<0.001)$, but still affects.

\subsubsection{Leadership Style Test Results on Organizational Culture}

$\mathrm{H} 2$ test results indicate that leadership style has a positive relationship to organizational culture. If the leadership style is good, then PT. WKS will be able to form a good organizational culture. Conversely, if the leadership style is not good, then at PT. WKS will form an unfavorable organizational culture.

In changing leaders, several policies differ from one leader to another. A leader has his style in leading the organization. Employees from each leader feel several differences. The culture applied by the leadership influences the organizational culture. The behavior of the leader will be an example for his subordinates. Subordinates may apply the character that the leader carries. Organizational culture will be formed from the habits of employees.

Culture is defined as a mixture of values, communication beliefs, and behaviors that serve as guidelines for humans who are influenced by behavior, norms, and beliefs that become strong communication among workers [35]. Harbi et al. [36] argue that leadership is a process based on the interaction between leaders and subordinates to become effective from change and development and influence the behavior and motivation of followers. So leadership can form a conceptualized value and become a value applied in an organization to become a behavior guide for employees. Ratnasari et al. [37] supported that leadership affects organizational culture, where P value $0.000<\mathrm{P} 0.005$.

\subsubsection{Results of the Work Environment Test on Organizational Culture}

The $\mathrm{H} 3$ test results show that the work environment has a positive relationship to organizational culture. If the work environment is good, then PT. WKS will be able to form a good organizational culture. Conversely, if the work environment is not good, then at PT. WKS will form an unfavorable organizational culture.

In the period 2018 to 2020 at PT. WKS has provided tools and work facilities that are useful to support performance. Sometimes the lack of availability of employees and equipment makes the work unit jealous. Thus, prejudice will arise among co-workers. Organizational culture will be less good.

Conversely, if the work equipment and labor are sufficiently available, prejudice against colleagues will be good. It is feared that a bad work environment will become a habit in the organization. The habits that grow in the organization will become a culture.

Based on the discussion of the above hypotheses, it can be concluded that the work environment at PT. WKS influences organizational culture. Under what is stated by Agwu \& Onwuegbuzie, [38], the environment is the factors outside and within reach of an organization that can create an opportunity or threat. Meanwhile, according to Panda \& Gupta, [39] organizational culture is conceptualized and shared on the beliefs and values of the organization that help shape employee behavior. Relationships between colleagues, between superiors and subordinates are a form of the nonphysical work environment. This work environment is a form of employee behavior. A good non-physical work environment can be improved to become a culture in the organization. It is supported by Girdwichai \& Sriviboon, [40] which proves that the work environment has an important role in motivating employees to improve their performance.

\subsubsection{Organizational Culture Test Results on Job Satisfaction}

The H4 test results show that organizational culture has a positive relationship with job satisfaction. If the organizational culture is good, then PT. WKS will be able to increase the job satisfaction of its employees. Conversely, if the organizational culture is not good, then PT. WKS will reduce the level of job satisfaction. 
During the period from 2018 to 2020 at PT. WKS has increased the level of job satisfaction. It can be seen from the factors of earlier arrival, decreased absenteeism levels, and increased employee participation in activities carried out by PT. WKS. Willing to come to work, even on holidays, and not given overtime pay. Conversely, employee job dissatisfaction can be seen from frequent late arrivals, high absenteeism levels, and unwillingness to participate in activities carried out by PT. WKS, the rest time is too long.

According to Hakim [41], job satisfaction includes reactions or cognitive, affective, and evaluative. It states that job satisfaction is "a happy emotional state or positive emotion that comes from a person's job appraisal or work experience". Positive behavior from employees, good norms in the organization, harmonious communication among employees will be a good organizational culture. Employees will feel comfortable, calm, and happy with the situation. It will encourage employees to improve their performance. Research conducted by Purwoharsojo et al. [42] proves that organizational culture is related to employee job satisfaction.

\subsubsection{Leadership Style Test Results Against Job Satisfaction}

H5 test results indicate that leadership style has a positive relationship to job satisfaction. If the leadership style suits the circumstances of employees who have various characters, there may be many different levels of job satisfaction. A leadership style that all elements can accept will get positive responses from employees. Conversely, suppose the leadership style is not in accordance with the wishes of employees and the organization. In that case, there will be an attitude of indifference and even rejection of policies from the leadership. As a result, it will reduce the level of job satisfaction.

In changing leaders, several policies differ from one leader to another. A leader has his style in leading the organization. Employees from each leader feel several differences. The leadership style applied by the leader influences job satisfaction. There are several types of leadership, among others: leaders who only want employees to be required to do work continuously, encourage subordinates to be smart in doing work, and be involved in education and training to achieve the organization's goals.

Based on the discussion of the above hypotheses, it can be concluded that the leadership style at PT. WKS influences job satisfaction. It is consistent with what Yukl expressed, [43] a leader selects, trains and guides one or more people and because people enthusiastically coordinate their efforts to achieve organizational goals. It is supported by research conducted by Boamah et al. [44]. The proof of the hypothesis is that transformational leadership and empowering leadership have an influence on job satisfaction $(\beta=.21, \alpha<.05 ; \beta=.23, \alpha<.05)$. Adverse leadership has a negative effect on job satisfaction $(ß=-.17, \alpha<.10)$.

\subsubsection{Work Environment Test Results on Job Satisfaction}

The H6 test results show that the work environment has a positive relationship with job satisfaction. PT. WKS has provided laboratory equipment, physical examination equipment, computers, weighing equipment, database, additional honorary staff, and civil servants, which are useful for supporting performance. With good performance, it is hoped that it will provide satisfaction for employees, organizations, and service users of PT. WKS.

One form of employee job satisfaction can be seen from the factors of earlier arrival decreased absenteeism levels, increased employee participation in activities carried out by PT. WKS. Willing to come to work, even on holidays, and not given overtime pay. Conversely, employee job dissatisfaction can be seen from frequent late arrivals, high absenteeism levels, unwillingness to participate in activities carried out by PT. WKS, the rest time is too long.

Based on the discussion of the above hypotheses, it can be concluded that the work environment at PT. WKS influences organizational culture. Under Ramli's opinion, [45] the work environment is everything around the worker and can affect him in carrying out the duties assigned to him. According to Tatar, [46] job satisfaction is important, not only for employees but also for the organization. The urgency is related to the empirical facts that satisfaction shows the results of work experience and high disappointment levels that help show organizational problems that need attention. The work environment is a source of supporting employee performance. The availability of equipment and the relationship between coworkers and superiors will impact the comfort and serenity of employees in carrying out their duties. Employee performance will increase due to the availability of work equipment and good working relationships. With the increase in employee performance, it is expected that the level of attendance in the office will be good, the level of absenteeism is low, involvement in activities in the organization will increase. It is a form of employee satisfaction level. Support for this theory is provided by research conducted by Shahin et al. [47], which proves that one of the work environment factors is regulation. Clear regulations play an important role in employee commitment (Mean $=3.784, \mathrm{SD}$ $=0.966$ ) , for their job. The findings indicate that there is a strong and positive relationship between the variables of job 
satisfaction and job commitment. It suggests that a qualitative survey on public services in Nigeria is more committed to their jobs when employees are more satisfied with their jobs. Meanwhile, research conducted by Muhammad Dhamija et al. [43] proved the work environment, $(\beta=0.233)$ and $(\mathrm{p}<0.000)$, which means that the work environment contributes $30 \%$ to job satisfaction.

\subsubsection{Leadership Style Test Results through Organizational Culture, Leadership Style Against Job Satisfaction}

In this study, there is an intervening variable, namely organizational culture. A variable is called an intervening variable if the variable affects the relationship between the independent and dependent variables.

Table 4 Structural Relationships $\mathrm{X} 1 \rightarrow \mathrm{Y} \rightarrow \mathrm{Z}$

\begin{tabular}{|l|l|l|l|}
\hline $\begin{array}{l}\text { Hypothes } \\
\text { is }\end{array}$ & $\begin{array}{l}\text { Variable } \\
\text { Relationships }\end{array}$ & $\begin{array}{l}\text { Sobel } \\
\text { Test }\end{array}$ & $\begin{array}{l}\text { Informati } \\
\text { on }\end{array}$ \\
\hline $\mathrm{H} 7$ & $\mathrm{X} 1 \rightarrow \mathrm{Y} \rightarrow \mathrm{Z}$ & 0,660 & $\begin{array}{l}\text { Be } \\
\text { accepted }\end{array}$ \\
\hline
\end{tabular}

Source: Data processing, 2021

The indirect effect of $\mathrm{X} 1$ to $\mathrm{Z}$ through $\mathrm{Y}$ is calculated by multiplying the path $\mathrm{X} 1 \rightarrow \mathrm{Y}(\mathrm{a})$ by the path $\mathrm{Y} \rightarrow \mathrm{Z}(\mathrm{b})$ or ab. Based on the calculation, the error coefficient $=0.660$ is obtained. Furthermore, suppose the direct influence between leadership style and job satisfaction is compared with the estimated coefficient value of 0.038 . In that case, the result will be that this value will be greater than the value of the indirect effect obtained from the multiplication of the coefficient values. Estimated $\mathrm{H} 2$ and $\mathrm{H} 4(0.454 \times 0.840=0.3816)$. Thus, because the estimated coefficient for direct influence is greater than indirect $(0.038<0.3816)$, it means that a weaker leadership style is directly related to job satisfaction without mediating organizational culture variables. It is in line with research conducted by Mahmood [48] stated that leadership style and job satisfaction independently and a combination of performance have been tested using multiple regression analysis.

\subsubsection{Test Results Through Organizational Culture, Work Environment Affects Job Satisfaction}

The Sobel test is carried out by testing the strength of the indirect effect of the independent variable X2 on the dependent variable $(\mathrm{Z})$ through the intervening variable (Y).

Table 5 Structural Relationships $\mathrm{X} 2 \rightarrow \mathrm{Y} \rightarrow \mathrm{Z}$

\begin{tabular}{|l|l|l|l|}
\hline Hypothesis & $\begin{array}{l}\text { Variable } \\
\text { Relationships }\end{array}$ & $\begin{array}{l}\text { Sobel } \\
\text { Test }\end{array}$ & $\begin{array}{l}\text { Informatio } \\
\text { n }\end{array}$ \\
\hline $\mathrm{H} 7$ & $\mathrm{X} 2 \rightarrow \mathrm{Y} \rightarrow \mathrm{Z}$ & 0,073 & Rejected \\
\hline \multicolumn{2}{|c|}{ Source: Data processing, 2021} \\
\hline
\end{tabular}

The indirect effect of $\mathrm{X} 2$ to $\mathrm{Z}$ through $\mathrm{Y}$ is calculated by multiplying the path $\mathrm{X} 2 \rightarrow \mathrm{Y}(\mathrm{a})$ by the path $\mathrm{Y} \rightarrow \mathrm{Z}(\mathrm{b})$ or ab. Based on the calculation, the error value of the coefficient $\mathrm{ab}=0.0731$ is obtained. Furthermore, when compared between the direct effect of the work environment on job satisfaction with the estimated coefficient value of 0.037 , the results will be that this value will be greater than the value of the indirect effect obtained from the multiplication of the estimated coefficient values $\mathrm{H} 3$ and $\mathrm{H} 4(0.454 \times 0.840=0.3816)$. Thus, because the error coefficient for direct influence is greater than indirect $(0.037<0.0731)$, it means that the work environment has no direct effect on job satisfaction without going through the mediation of organizational culture variables.

\section{Conclusion}

- The leadership style has a positive and significant influence on the work environment.

- Leadership style has a positive and significant influence on organizational culture.

- The work environment does not have a positive and insignificant influence on organizational culture.

- Organizational culture has a positive and significant influence on job satisfaction.

- Leadership style does not affect and is significant on job satisfaction variables.

- The work environment does not have a positive and insignificant influence on job satisfaction.

- Leadership style through organizational culture has a positive and significant effect on job satisfaction. 
- The work environment through organizational culture does not have a positive and significant effect on job satisfaction.

\section{Suggestion}

- The leadership style adopted by a leader will be able to create work situations for employees. Therefore it is necessary to have a leadership style that can improve a more harmonious, conducive work environment so that employees will feel a comfortable and calm work environment.

- A leader can apply a leadership style that is in accordance with the organization's goals and does not conflict with the organizational culture. Employees can feel that their habits do not have to change drastically to follow a leader's style. This atmosphere will make employees feel familiar with the habits they carry out. The culture applied by employees will not change significantly as a result of the leadership style.

- It was improving the work environment, such as increasing communication between employees, employees, and superiors, the existence of meetings that can strengthen friendship and meet the needs of employees so that employees will feel comfortable carrying out their duties. This condition can be used as a habit so that it will be attached to every employee. It will reduce distrust and suspicion among co-workers. By increasing a good work environment, it is hoped that the organizational culture will be better.

- Need to increase the sense of help among colleagues, increase employee creativity, increase cooperation in carrying out tasks that can be applied in work culture. Because organizational culture is proven to influence job satisfaction, the organizational culture needs to be better improved to increase job satisfaction.

- Although the leadership style does not affect job satisfaction, all employees' leadership styles should be accepted so that employees will still be able to carry out the tasks given by the leadership without differences in procedures with those ordered by the leadership.

- Although the work environment does not influence job satisfaction, it would be nice if the existing work environment should be comfortable, calm, and safe. If employees carry out their duties comfortably, calmly, and safely, they will optimally carry out their work.

- The leadership style is proven to influence employee job satisfaction through work culture. It is necessary to apply a leadership style that is in accordance with the organization's circumstances to be able to improve the organizational culture to increase job satisfaction.

- Although the work environment does not influence job satisfaction through organizational culture, it is necessary to improve a good work environment, which will be able to shape the organizational culture to be better to increase job satisfaction

\section{Compliance with ethical standards}

\section{Acknowledgments}

The Authors would like to thank internal reviewers for suggestions in this manuscripts.

\section{Disclosure of conflict of interest}

The authors declare no conflict of interest

\section{Statement of informed consent}

Informed consent was obtained from all individual participants included in the study.

\section{References}

[1] Bambang Sugiarto. Persyaratan Pengelolaan Hutan Lestari Indonesian Forestry Certification Cooperation (Ifcc) Propinsi Jambi; Ringkasan Publik PT. Wirakarya Sakti-2021; Lembaga Sertifikasi PT. Bureau Veritas Indonesia. 2021.

[2] Maja Rožman, Tjaša Štrukelj. Organisational climate components and their impact on work engagement of employees in medium-sized organisations. 2020.

[3] Mohammad Yousef Abuhashesh, Rand Aldmour, Ra'Ed Masa'deh. Factors that affect Employees Job Satisfaction and Performance to Increase Customers' Satisfactions; Project: Factors that impact job satisfaction and performance among employees in the Jordanian industrial sector. 2019. 
[4] Okechukwu Omah, Onyebuchi Obiekwe. Impact of Employee Job Satisfaction on Organizational Performance; International Journal of Current Research. 2019; 6(12): 2343-403.

[5] Muhammad Irfani Hendri. The mediation effect of job satisfaction and organizational commitment on the organizational learning effect of the employee performance; The current issue and full text archive of this journal is available on Emerald Insight at. 2019.

[6] Ed Diener, Stuti Thapa, Louis Tay. Positive Emotions at Work; Annual Review of Organizational Psychology and Organizational Behavior. 2019; 7(1).

[7] Adriana AnaMaria Davidescu, Simona-Andreea Apostu, Andreea Paul, Ionut Casuneanu. Work Flexibility, Job Satisfaction, and Job Performance among Romanian Employees-Implications for Sustainable Human Resource Management. 2020.

[8] Abdul Haeba Ramli. Work Environment, Job Satisfaction And Employee Performance In Health Services; Business and Entrepreneurial Review (BER). 2019; 19(1): 29.

[9] Siti Karlina Hidayati, Badia Perizade, Marlina Widiyanti. Effect Of Work, Discipline And Work Environment To Performance Of Employees; International Journal of Scientific and Research Publications (IJSRP). 2019; 9(12): 96-43.

[10] Zulhamri Abdullah, Tham Yee Ling, Nuzatul Shima Sulaiman, Ras Afirina Mohd Radzi, Kinkin YS Putri. The Effects Of Verbal Communication Behaviors On Communication Competence In The Pharmaceutical Industry; Journal of Critical Reviews. 2020.

[11] Erna Paramita, Prihatin Lumbanraja, Yeni Absah. The Influence of Organizational Culture and Organizational Commitment on Employee Performance and Job Satisfaction as a Moderating Variable at PT. Bank Mandiri (Persero), Tbk; International Journal of Research and Review. 2020.

[12] Dawn Strait. What is Leadership? Researchgate. 2020.

[13] Fatma Sonmez Cakir \& Zafer Adiguzel. Analysis of Leader Effectiveness in Organization and Knowledge Sharing Behavior on Employees and Organization. 2020.

[14] Roy Setiawan. Leaders' Perspective On Leader Member Exchange: A Conceptual Review; A multifaceted review journal in the field of pharmacy. 2020.

[15] Francesco Sulla, Silvia Perini. Positive Psychology at School: the effect of cueing system and Visual Performance Feedback on teacher use of approval in the classroom; Researchgate. 2018.

[16] Aram Hanna Massoudi \& Dr. Samir Salah Aldin Hamdi. The Consequence of work environment on Employees Productivity; IOSR Journal of Business and Management. 2019; 19(01): 35-42.

[17] Guillermo Fuertes, Miguel Alfaro, Manuel Vargas, Sebastian Gutierrez, Rodrigo Ternero, Jorge Sabattin. Conceptual Framework for the Strategic Management: A Literature Review-Descriptive; Journal Of Engineering. 2020.

[18] Elok Mahmud Putri, Vivin Maharani, Achmad Sani Supriyanto, Zaim Mukaffi. The Effect Of Work Environment On Employee Performance Through Work Discipline; International Journal of Research. 2019; 7(4): 132-140.

[19] Khaled adnan Bataineh. Impact of Work-Life Balance, Happiness at Work, on Employee Performance; International Business Research. 2019.

[20] Anastasios D. Diamantidis \& Prodromos D Chatzoglou. Factors affecting employee performance: an empirical approach; International Journal of Productivity and Performance Management. 2018; 68(1).

[21] Yasas Pathiranage. Organizational Culture and Business Performance: An Empirical Study; International Journal of Economics and Management. 2019; 6(6): 1-12.

[22] Eser Erdurmazl. Effects of Information Technologies on Organizational Culture: A Discussion Based on the Key Role of Organizational Structure. 2019.

[23] Yeti Kuswati. The Influence of Organizational Culture on Employee Performance; Budapest International Research and Critics Institute (BIRCI-Journal) Humanities and Social Sciences. 2020; 3(1): 296-302.

[24] Seyedeh Khadijeh Taghizadeh - Nastaran, Syed Abidur Rahman, Md. Mosharref Hossain \& Md Masudul Haque. Characteristics of organizational culture in stimulating service innovation and performance; Marketing Intelligence \& Planning ahead-of-print (ahead-of-print). 2019. 
[25] Szymon Dziuba, Manuela Ingaldi \& Marina Zhuravskaya. Employees' Job Satisfaction and their Work Performance as Elements Influencing Work Safety; Researchgate. 2020.

[26] Kalpathy Ramaiyer Subramanian. The Connection Between Your Employees And Customers: Researchgate.2018.

[27] Lixin Jiang \& Lindsey M. Lavaysse. Cognitive and Affective Job Insecurity: A Meta-Analysis and a Primary Study. 2018.

[28] Moh. Sutoro. Factors Affecting Job Satisfaction; Scientific Journal Of Reflection: Economic, Accounting, Management and Business. 2020; 3(4): 361-370.

[29] Sakinah mohd shukri, Johar MGM \& Jacquline Tham. How e-business platform channels influence chinese autoparts wholesale market?; Sys Rev Pharm 2020. 11(1):718-725

[30] Naresh K. Malhotra. Marketing Research: An Applied Orientation, 7th Edition. 2019.

[31] Ni Wayan Surya Wardhani, Waego Hadi Nugroho, Adji Achmad Rinaldo Fernandes \& Solimun. Structural Equation Modeling (Sem) Analysis With Warppls Approach Based On Theory Of Planned Behavior (TPB); Mathematics and Statistics. 2020; 8(3): 311-322, 2020

[32] Ebrahim Hasan Al Khajeh. Impact of Leadership Styles on Job Satisfaction. Journal of Human Resources Management Research. 2018.

[33] Katarzyna Kozioł-Nadolna. The Role of a Leader in Stimulating Innovation in an Organization. 2020. 10(59)

[34] Dana Al Rahbi, Khalizani Khalid \& Mehmood Khan. The Effects of Leadership Styles on Team Motivation. Academy of Strategic Management Journal. 2019.

[35] Tim Stobierski. How to Improve Cross-Cultural Communication in the Workplace. 2019.

[36] Jaithen Abdullah Al Harbi, Saud Alarifi \& Aissa Mosbah. Transformation leadership and creativity: Effects of employees pyschological empowerment and intrinsic motivation. 2019.

[37] Ratnasari SL, Sutjahjo G \& Adam. The effect of job satisfaction, organization, culture, and leadership on employee performance, Ann Trop Med \& Public Health. 2020. 23(S13A)

[38] M. E. Agwu \& H. N. Onwuegbuzie. Effects of international marketing environments on entrepreneurship development. Journal of Innovation and Entrepreneurship. 2018

[39] Abinash Panda \& Rajen K. Gupta. Understanding Organizational Culture: A Perspective on Roles for Leaders; Vikalpa. 2018. 26(4):3-19

[40] Luedech Girdwichai \& Chutikarn Sriviboon, 2020. Employee Motivation And Performance: Do The Work Environment And The Training Matter?; Journal of Security and Sustainability Issues. 2020. 9(4)

[41] Azis Hakim. Effect Of Compensation, Career Development, Work Environment On Job Satisfaction And Its Impact On Organizational Commitments In Pt Jakarta Tourisindo; Journal of Critical Reviews. 2020.

[42] Purwadi Purwoharsojo, Dio Caisar Darma \& Dedy Mirwansyah. Exploration of Leadership, Organizational Culture, Job Satisfaction, and Employee Performance; International Journals. 2020. 6(1).

[43] Gary Yukl. Effective Leadership Behavior: What We Know and What Questions Need More Attention; Academy of Management Perspectives. 2019. 26(4):66-85

[44] Sheila Boamah, Heather K. Spence Laschinger, Carol Anne Wong \& Sean P Clarke. Effect of transformational leadership on job satisfaction and patient safety outcomes; Nursing Outlook. 2019. 66(2).

[45] Abdul Haeba Ramli. Work Environment, Job Satisfaction And Employee Performance In Health Services; Business and Entrepreneurial Review (BER). 2019. 19(1):29

[46] Ali Tatar. Impact of Job Satisfaction on Organizational Commitment; Researchgate. 2020.

[47] Saeideh Shahin, Meaghan Reitzel, Briano Di Rezze, Sara Ahmed \& Dana Anaby. Environmental Factors that Impact the Workplace Participation of Transition-Aged Young Adults with Brain-Based Disabilities: A Scoping Review; International Journal of Environmental Research and Public Health. 2020.

[48] Pavitra Dhamija, Shivam Gupta \& Surajit Bag.. Measuring of Job Satisfaction: The Use of Quality of Work Life Factors; Benchmarking An International Journal. 2018. 26(1). 